\title{
Microcystin Levels in Selected Cyanobacteria Exposed to Varying Salinity
}

\author{
Dy'mon Walker'1, Somayeh Gharaie Fathabad', Behnam Tabatabai' ${ }^{1}$, Sanjeeda Jafar ${ }^{2}$, \\ Viji Sitther ${ }^{*}$ (1)
}

\author{
${ }^{1}$ Department of Biology, Morgan State University, Baltimore, MD, USA \\ ${ }^{2}$ Medical Technology Program, Morgan State University, Baltimore, MD, USA \\ Email: *viji.sitther@morgan.edu
}

How to cite this paper: Walker, D., Fathabad, S.G., Tabatabai, B., Jafar, S. and Sitther, V. (2019) Microcystin Levels in Selected Cyanobacteria Exposed to Varying Salinity. Journal of Water Resource and Protection, 11, 395-403.

https://doi.org/10.4236/jwarp.2019.114023

Received: March 20, 2019

Accepted: April 23, 2019

Published: April 26, 2019

Copyright $\odot 2019$ by author(s) and Scientific Research Publishing Inc. This work is licensed under the Creative Commons Attribution International License (CC BY 4.0).

http://creativecommons.org/licenses/by/4.0/

\begin{abstract}
Microcystins produced by cyanobacteria pose a great threat to human health by releasing toxins upon cell death. In the present study, we studied microcystin production in the cyanobacterial strains Anabaena cylindrica (B629 and 2949) and Fremyella diplosiphon (SF33) exposed to 1, 2 and 4 g/L sodium chloride $(\mathrm{NaCl})$. Cultures grown for 7 days in BG11/HEPES medium were pelleted, re-grown in the corresponding $\mathrm{NaCl}$ levels, and enzyme linked immunosorbent assay (ELISA) performed. ELISA assays revealed enhanced microcystin production in $A$. cylindrica $\mathrm{B} 629$ exposed to $4 \mathrm{~g} / \mathrm{L} \mathrm{NaCl}$ and $A$. cylindrica 29414 exposed to 2 and $4 \mathrm{~g} / \mathrm{L} \mathrm{NaCl}$, after growth in the corresponding $\mathrm{NaCl}$ levels for 14 days. We observed a significant decrease ( $\mathrm{p}>$ 0.05 ) in microcystin levels in the control strains after exposure to $\mathrm{NaCl}$ for 5 days. After exposure to 1,2 , or $4 \mathrm{~g} / \mathrm{L} \mathrm{NaCl}$ for 10 days, no microcystin release was observed in A. cylindrica B629, A. cylindrica 29414 or F. diplosiphon SF33. Sodium dodecyl sulfate polyacrylamide gel electrophoresis identified the presence of an additional band at $120-130 \mathrm{kDa}$ in A. cylindrica $\mathrm{B} 629 \mathrm{ex}-$ posed to 2 and $4 \mathrm{~g} / \mathrm{L} \mathrm{NaCl}$, and at $14 \mathrm{kDa}$ in cultures amended with 1 and 2 $\mathrm{g} / \mathrm{L} \mathrm{NaCl}$ as well as the untreated control, indicating that exposure to salinity induces alterations in protein expression.
\end{abstract}

\section{Keywords}

Cyanotoxin, ELISA, Harmful Algal Blooms, Protein Expression, Sodium Chloride

\section{Introduction}

Massive proliferation of cyanobacterial blooms has severe ecological impacts including changes in biodiversity and depletion of available oxygen resulting from 
eutrophication [1]. Certain cyanobacterial species that are known to form harmful algal blooms (HABs) produce toxins impacting human health and aquatic biota. The intracellular cyanotoxins released by the rupture and disintegration of cyanobacterial cell membrane during cell lysis trigger these toxins to become extracellular and persist in marine environments for several months [2] [3]. Microcystins, the most significant cyanotoxins, are known to inhibit liver function, disrupt sperm motility and morphology, cause intestinal inflammation, impair spatial memory, and trigger neuronal degenerative changes and apoptosis in vertebrates [4] [5] [6] [7]. At the molecular level, microcystins also affect humans by binding to okadaic acid receptors, which promote tumor formation and inhibit serine/threonine protein phosphatases 1 (PP1) and 2A (PP2A) [8].

Various abiotic factors such as light and temperature influence microcystin concentration by influencing the abundance of microcystin-producing strains as well as by regulating extracellular and intracellular abundance and toxicity [9]. In addition, nitrogen, phosphorus, and HAB-causing chemicals from agricultural runoff are reported to increase microcystin production [10]. Of these factors, salinity has a significant impact on water quality and aquatic life due to the enormous amounts of de-icing salts released into water bodies. Studies have shown that salt from the run-off is washed downstream, thus increasing the salinity of streams and lakes [11] [12].

While microcystin production in various cyanobacterial species has been reported [13] [14], there is no comparative study of microcystins produced among the cyanobacteria, Anabaena cylindrica B629 and 29414 (known to produce microcystin) and Fremyella diplosiphon SF33 (not reported to produce microcystin). In this study, the impact of 1,2 , and $4 \mathrm{~g} / \mathrm{L}$ sodium chloride $(\mathrm{NaCl})$ on total microcystin production in these strains was studied. In addition, we identified changes in protein expression in these strains exposed to 1,2 and $4 \mathrm{~g} / \mathrm{L} \mathrm{NaCl}$ using sodium dodecyl sulfate polyacrylamide gel electrophoresis (SDS-PAGE).

\section{Materials and Methods}

\subsection{Strains and Culture Conditions}

A. cylindrica B629 was obtained from the UTEX culture collection, A. cylindrica 29414 from the ATCC collection, and F. diplosiphon SF33 strain from Dr. Montgomery's laboratory (Michigan State University).Cultures were grown on BG-11 solid medium containing $20 \mathrm{mM}$ HEPES at $28^{\circ} \mathrm{C}$ for $5-7$ days under continuous white light adjusted to $30 \mu \mathrm{mol} \cdot \mathrm{m}^{-2} \mathrm{~s}^{-1}$ using a LI-190SA quantum sensor (Li-Cor, USA). Cells were transferred to $125 \mathrm{~mL}$ Erlenmeyer flasks containing $50 \mathrm{~mL}$ liquid BG11/HEPES at an initial optical density of 0.1 at $750 \mathrm{~nm}$ $\left(\mathrm{OD}_{750}\right)$. Cultures were grown under continuous shaking at $170 \mathrm{rpm}$ at $28^{\circ} \mathrm{C}$. Three replicate treatments were maintained and the experiment repeated once.

\subsection{Culture Preparation and Enzyme-Linked Immunosorbent Assay (ELISA)}

Cyanobacterial cultures were grown in salt free BG11/HEPES medium for 7 
days. At day 7, cells were centrifuged at $6000 \mathrm{rpm}$ for $4 \mathrm{~min}$, supernatant discarded, and the pellet transferred to BG11/HEPES supplemented with 1,2, or 4 $\mathrm{g} / \mathrm{L} \mathrm{NaCl}$. Three replicates were maintained for each strain tested. Cultures grown in the absence of $\mathrm{NaCl}$ served as control. On day 14, cells were disrupted using a sonicator (Fisher Scientific, CL18) at 100\% amplification for $90 \mathrm{~s}$ and stored at $-20^{\circ} \mathrm{C}$ overnight.

To determine the microcystin levels, ELISA was performed using Microcystin-ADDA ELISA test kit (ABRAXIS, Inc.). In this method, $50 \mu \mathrm{L}$ of the standard, control, or treatment was added to the test-strip wells followed by $50 \mu \mathrm{L}$ antibody solution. Wells were covered with parafilm, contents mixed in a rocking shaker for 30 seconds, followed by incubation at room temperature for 90 minutes. Strips were washed three times by $1 \times$ wash buffer solution, decanted, and plate inverted for roughly one minute. Then, $100 \mu \mathrm{L}$ enzyme conjugate solution was added to each well, covered with parafilm, mixed in a shaker for 30 seconds, and incubated at room temperature for 30 minutes. Wells were washed with the same buffer thrice, decanted, and inverted for about one minute. Then, $100 \mu \mathrm{L}$ of substrate (color) solution was added to individual wells followed by mixing for 30 seconds, and incubated at room temperature for 30 minutes. Finally, $50 \mu \mathrm{L}$ of stop solution was added and absorbance was read at $450 \mathrm{~nm}$ using a microplate ELISA photometer within 15 minutes. Microcystin concentrations were determined by comparison to the supplied calibrators and the experiment repeated once [14].

\subsection{Microcystin Production over Time}

A. cylindrica B629 and 29414 and F. diplosiphon SF33 strains were grown in BG-11/HEPES under conditions mentioned above for a period of 10 days and 1 $\mathrm{mL}$ aliquots obtained from each strain at 5 -day intervals (Days $0,5,10$ ). Cells were sonicated at $100 \%$ amplification for $90 \mathrm{~s}$ and stored at $-20^{\circ} \mathrm{C}$ overnight. ELISA assays were performed the following day as mentioned above.

\subsection{Comparison of Protein Expression in Cyanobacterial Cultures Exposed to Varying $\mathrm{NaCl}$ Levels Using 1D-PAGE}

Total protein was extracted according to the protocol described by Kendrick Labs (USA). Protein isolation was performed using osmotic lysis buffer (10 mM Tris, $\mathrm{pH} 7.4$, and $0.3 \%$ SDS) containing $10 \times$ nuclease stock, $100 \times$ phosphatase inhibitor stocks I \& II, and 100× protease inhibitor stock according to the manufacturer's protocol. Five-day old A. cylindrica B629 and 29414 and F. diplosiphon SF33 cultures were grown on liquid BG-11/HEPES supplemented with 1, 2 , and $4 \mathrm{~g} / \mathrm{L} \mathrm{NaCl}$ as mentioned above. Cells grown in the absence of $\mathrm{NaCl}$ served as control. Approximately $50-75 \mathrm{mg}$ of the control and $\mathrm{NaCl}$-treated cells were collected, vortexed, and lysed by inversion in $500 \mu \mathrm{l}$ of the osmotic lysis buffer master mix followed by $30 \mathrm{~s}$ sonication at $100 \%$ power. Aliquots of 25 $\mu \mathrm{l}$ were removed from each sample and protein concentration determined using the Pierce Bicinchoninic acid (BCA) Assay (Thermo Fisher Scientific, USA). 
SDS boiling buffer without BME (5\% SDS, 10\% glycerol and $60 \mathrm{mM}$ Tris, $\mathrm{pH}$ 6.8) $(500 \mu \mathrm{l})$ was then added to samples and heated in a water bath at $98^{\circ} \mathrm{C}$ for 5 min. Samples were lyophilized and re-dissolved to $4 \mathrm{mg} / \mathrm{ml}$ in 1:1 mixture of diluted SDS boiling buffer (5\% SDS, 5\% BME, 10\% glycerol and $60 \mathrm{mM}$ Tris, pH 6.8) and urea sample buffer (9.5 M urea, 2\% w/v IGEPAL CA-630, 5\% BME). Aliquots $(50 \mathrm{mg}$ ) of each sample were run on $10 \%$ polyacrylamide gel in a MiniProtean Tetra Gel system at $150 \mathrm{~V}$ for $90 \mathrm{~min}$. The gel was washed three times (5 min each rinse) with distilled water and protein bands visualized using Simply Blue stain. A comprehensive work flow of steps followed in this study is provided in Figure 1.

\section{Results}

\subsection{Microcystin Quantification in A. cylindrica B629 and 29414 and F. diplosiphon SF33}

We observed a significant increase $(\mathrm{p}<0.05)$ in microcystin levels of $A$. cylindrica $\mathrm{B} 629$ and $A$. cylindrica 29414 strains exposed to $4 \mathrm{~g} / \mathrm{L} \mathrm{NaCl}$ compared to their corresponding control (Figure 2, Table 1(a)). In addition, we observed a significant increase $(\mathrm{p}<0.05)$ in microcystin levels of $A$. cylindrica 29414 exposed to $4 \mathrm{~g} / \mathrm{L} \mathrm{NaCl}$ compared to F. diplosiphon SF33.

\subsection{Effect of $\mathrm{NaCl}$ on Microcystin Production in A. cylindrica $\mathrm{B} 629$ and 29414 and $F$, diplosiphon SF33 over a Period of 10 Days}

We monitored microcystin production for a period of 10 days to identify changes in microcystin release over time. Our results revealed no significant differences ( $\mathrm{p}>0.05)$ in microcystin levels at day 0 in $F$. diplosiphon SF33, A. cylindrica B629 and 29414 strains grown in salt-free medium (Figure 3; Table 1(a)). In addition, we observed a significant decrease ( $\mathrm{p}>0.05$ ) in microcystin levels of $A$. cylindrica B629 and F. diplosiphon SF33 grown in salt-free medium after five

Table 1. (a) Significance values for studies on microcystin quantification in Anabaena cylindrica B629 and 29414 and Fremyella diplosiphon SF33 and (b) Effect of sodium chloride $(\mathrm{NaCl})$ on microcystin production over a period of 10 days.

(a)

\begin{tabular}{ccc}
\hline Treatment pairs & p-value & Inference \\
\hline B629 vs 29414 controls & 0.0492958 & ${ }^{*} \mathrm{p}<0.05$ \\
29414 vs SF33 $4 \mathrm{~g} / \mathrm{L} \mathrm{NaCl}$ & 0.0294261 & ${ }^{*} \mathrm{p}<0.05$ \\
$294141 \mathrm{~g} / \mathrm{L} \mathrm{NaCl}$ vs $294142 \mathrm{~g} / \mathrm{L} \mathrm{NaCl}$ & 0.0337434 & ${ }^{*} \mathrm{p}<0.05$ \\
$294141 \mathrm{~g} / \mathrm{L} \mathrm{NaCl}$ vs $294144 \mathrm{~g} / \mathrm{L} \mathrm{NaCl}$ & 0.0157504 & ${ }^{*} \mathrm{p}<0.05$ \\
\hline
\end{tabular}

(b)

\begin{tabular}{ccc}
\hline Treatment pairs & p-value & Inference \\
\hline B629 cultures after day 5 & 0.0061444 & ${ }^{* *} \mathrm{p}<0.01$ \\
SF33 cultures after day 5 & 0.0363168 & ${ }^{*} \mathrm{p}<0.05$ \\
\hline
\end{tabular}




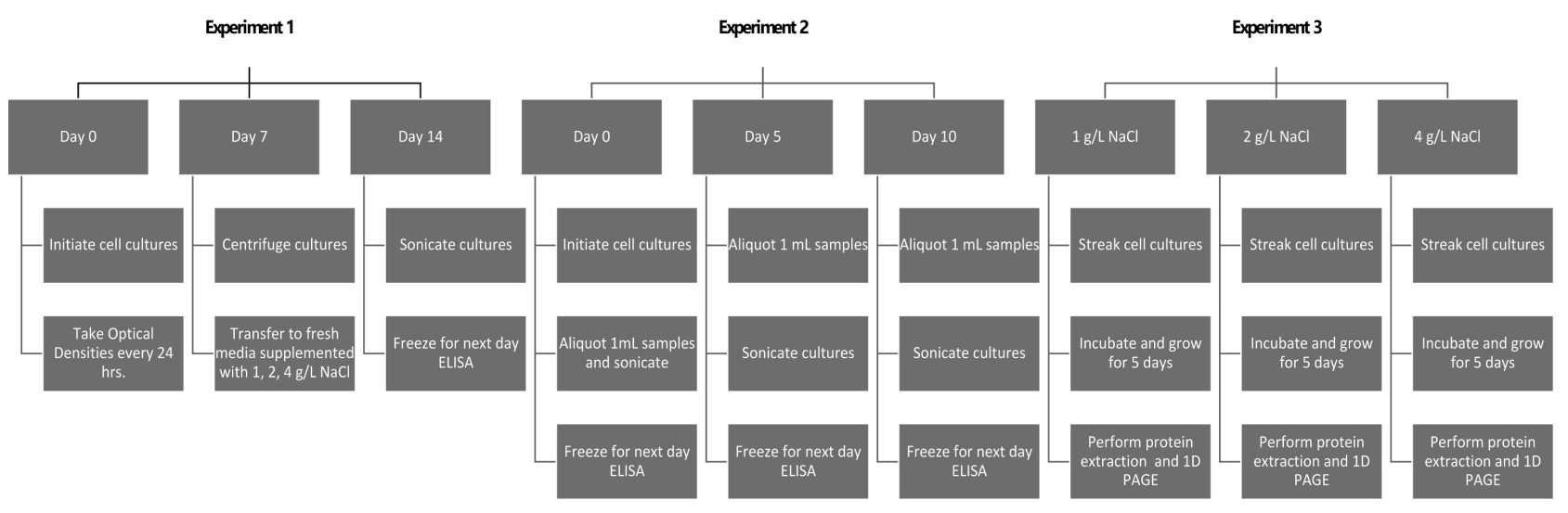

Figure 1. Summarized timeline of experiments followed in the present study.

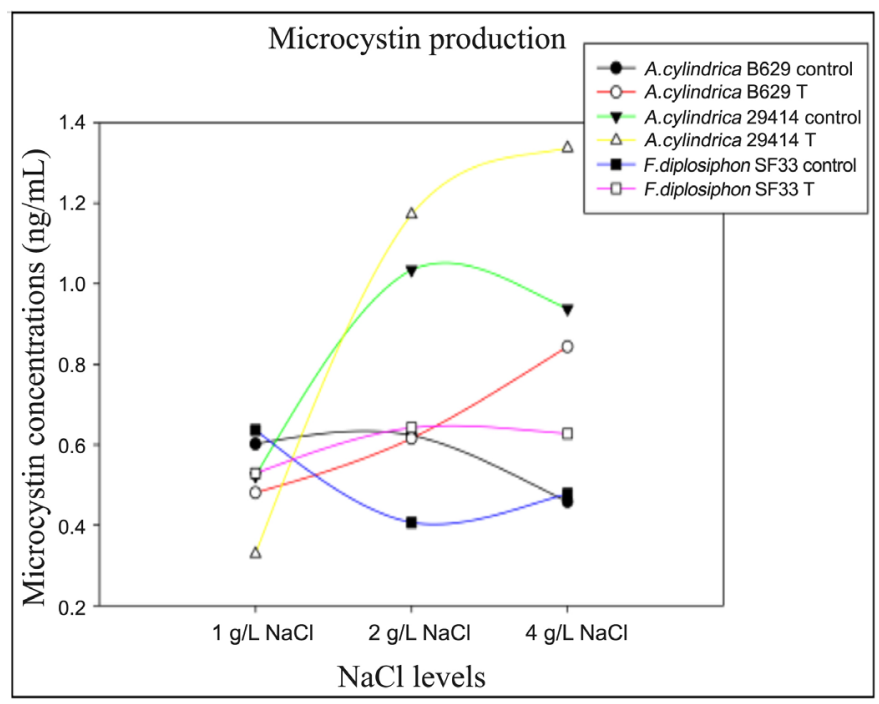

Figure 2. Microcystin production in Anabaena cylindrica B629 and 29414 and Fremyella diplosiphon SF33 cultures exposed to $1 \mathrm{~g} / \mathrm{L}, 2 \mathrm{~g} / \mathrm{L}$, and $4 \mathrm{~g} / \mathrm{L}$ sodium chloride $(\mathrm{NaCl})$ and untreated control.

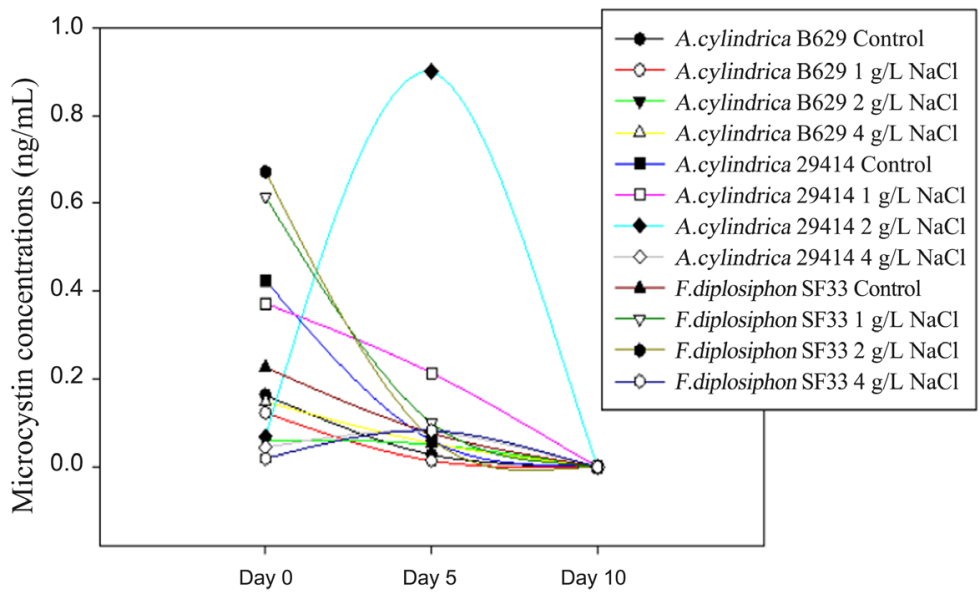

Figure 3. Microcystin production in Anabaena cylindrica B629 and 29414 and Fremyella diplosiphon SF33 cultures exposed to sodium chloride $(\mathrm{NaCl})$ over a period of 0,5 , and 10 days. 
days compared to their initial levels. At day 10, no microcystin was detected in all the three strains exposed to 1,2 , and $4 \mathrm{~g} / \mathrm{L} \mathrm{NaCl}$.

\subsection{Protein Expression in A. cylindrica B629 and 29414, and F. diplosiphon SF33 Cultures Exposed to $\mathrm{NaCl}$}

SDS-PAGE revealed differential protein expression in cultures exposed to 1,2 , and $4 \mathrm{~g} / \mathrm{L} \mathrm{NaCl}$ over a period of 10 days. A single band at $120-130 \mathrm{kDa}$ was visualized only in cultures treated with $2 \mathrm{~g} / \mathrm{L}$ and $4 \mathrm{~g} / \mathrm{L} \mathrm{NaCl}$ (Figure 4). A $14 \mathrm{kDa}$ band was observed in control $A$. cylindrica cultures as well as those exposed to 1 and $2 \mathrm{~g} / \mathrm{L} \mathrm{NaCl}$. Additionally, our results revealed the presence of a band at 175 $\mathrm{kDa}$ in all $A$. cylindrica B629 cultures. By contrast, the band at $120-130 \mathrm{kDa}$ was not observed in A. cylindrica 29414 and F. diplosiphon SF33.

\section{Discussion}

Increasing frequency and intensity of HABs pose serious environmental concerns resulting in high mortality rates of invertebrate and vertebrates and plant populations [11]. HABs are caused by nutrient overload or chemical pollutants commonly found in products used in agriculture [13]. A number of cyanobacterial species including Microcystis, Anabaena, Oscillatoria, Nodularia, Nostoc, Gloeotrichia, Anabaenopsis, and terrestrial Hapalosiphon sp. have been recognized to produce microcystin [3] [12] [14].

Several studies have reported the impact of environmental factors such as light and temperature on the prevalence of HABs [9]. In addition, various nutrients such as nitrogen and phosphorus have been reported to affect cyanotoxin

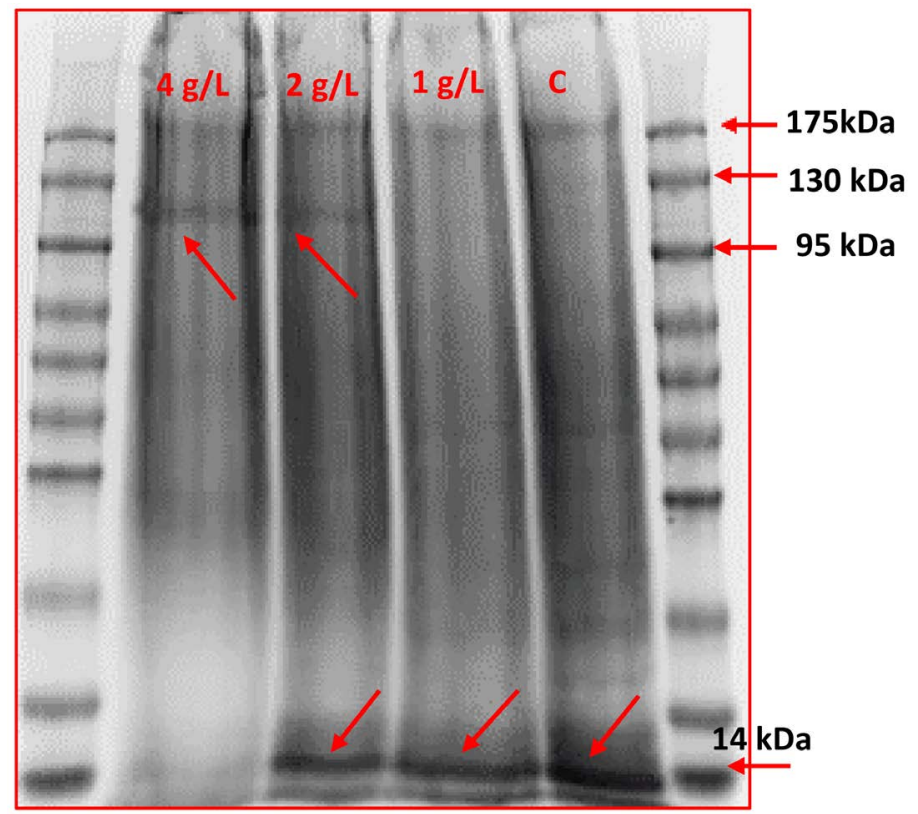

Figure 4. Sodium dodecyl sulfate polyacrylamide gel electrophoresis (SDS-PAGE) of Anabaena cylindrica $\mathrm{B} 629$ treated with 1,2 , and $4 \mathrm{~g} / \mathrm{L}$ sodium chloride $(\mathrm{NaCl})$ and untreated control (C). 
release [15]. However, a study on the impact of varying salinity exposure on microcystin production and protein expression in A. cylindrica sp. and F. diplosiphon has not been clearly elucidated. Our findings indicate increased microcystin levels in A. cylindrica B629 cultures exposed to $4 \mathrm{~g} / \mathrm{L} \mathrm{NaCl}$, and $A$. cylindrica 29414 supplemented with 2 and $4 \mathrm{~g} / \mathrm{L} \mathrm{NaCl}$ (Figure 2), suggesting that higher $\mathrm{NaCl}$ levels could lead to enhanced microcystin release. These results are in accordance with those of Engström-Öst et al. [16] and Tonk et al. [17], who reported that salinity influences extracellular microcystin production in Anabaena and other microcystin-producing species.

Further, results of our study revealed a correlation in microcystins produced by these strains over a period of 10 days in response to salt shock. At day 5, microcystin level decreased in A. cylindrica B629 relative to day 0 (Figure 3), suggesting that prolonged exposure to $\mathrm{NaCl}$ could have led to the degradation of microcystins. These findings suggest that microcystin levels vary during the cell growth cycle in the $A$. cylindrica strains. No microcystin was detected at day 10 in all three strains exposed to the varying $\mathrm{NaCl}$ concentrations tested. In a similar study by Tonk et al. [17], microcystin concentrations produced by Microcystis aeruginosa were found to increase at salinity levels above $10 \mathrm{~g} / \mathrm{L}$.

The presence of an additional band at $120-130 \mathrm{kDa}$ in A. cylindrica B629 cultures exposed to 2 and $4 \mathrm{~g} / \mathrm{L} \mathrm{NaCl}$, and a band at $14 \mathrm{kDa}$ in cultures exposed to 0,1 and $2 \mathrm{~g} / \mathrm{L} \mathrm{NaCl}$ (Figure 4) suggests that elevated levels of $\mathrm{NaCl}$ could result in alterations at the protein level. Since the $14 \mathrm{kDa}$ microcystin-associated protein histidine phosphatase dephosphorylates ATP-citrate lyase [18], presence of the band at this specific size for A. cylindrica B629 control and cultures exposed to 1 and $2 \mathrm{~g} / \mathrm{L} \mathrm{NaCl}$ suggests ATP dephosphorylating properties, however high salinity levels may deactivate these mechanisms.

\section{Conclusion}

In summary, our results indicate that exposure of these cyanobacterial strains to $\mathrm{NaCl}$ could induce microcystin production and expression of ATP-citrate lyase dephosphorylating proteins. While lower salinity levels were tested in this study, it is possible that exposure to elevated $\mathrm{NaCl}$ levels will offer a more comprehensive insight on the effect of $\mathrm{NaCl}$ on microcystin production and release. Future studies will also aim to investigate alterations in protein expression in these strains using matrix-assisted laser desorption/ionization time-of-flight/time-of-flight mass spectrometry to identify specific microcystin-associated proteins. These studies will enhance our understanding of microcystins on cellular and metabolic processes, and provide pathways to mitigate their detrimental effects on the hydrosphere.

\section{Acknowledgements}

This study was supported by the National Institute of General Medical Sciences of the National Institutes of Health awards UL1GM118973 and TL4GM118974 
awarded to Morgan State University. The authors thank Mollie Lange (Morgan State University) for critical reading of the manuscript.

\section{Conflicts of Interest}

The authors declare no conflicts of interest regarding the publication of this paper.

\section{References}

[1] Bhadauriya, P., Gupta, R., Singh, S. and Bisen, P.S. (2007) Physiological and Biochemical Alterations in a Diazotrophic Cyanobacterium Anabaena cylindrica under $\mathrm{NaCl}$ Stress. Current Microbiology, 55, 334-338.

https://doi.org/10.1007/s00284-007-0191-1

[2] Carmichael, W.W. (1992) Cyanobacteria Secondary Metabolites-The Cyanotoxins. Journal of Applied Bacteriology, 72, 445-459. https://doi.org/10.1111/j.1365-2672.1992.tb01858.x

[3] Zanchett, G. and Oliveira-Filho, E. (2013) Cyanobacteria and Cyanotoxins: From Impacts on Aquatic Ecosystems and Human Health to Anticarcinogenic Effects. Toxins, 5, 1896-1917. https://doi.org/10.3390/toxins5101896

[4] Kozdęba, M., Borowczyk, J., Zimoląg, E., Wasylewski, M., Dziga, D., Madeja, Z. and Drukala, J. (2014) Microcystin-LR Affects Properties of Human Epidermal Skin Cells Crucial for Regenerative Processes. Toxicon, 80, 38-46.

https://doi.org/10.1016/j.toxicon.2014.01.003

[5] Lone, Y., Koiri, R.K. and Bhide, M. (2015) An Overview of the Toxic Effect of Potential Human Carcinogen Microcystin-LR on Testis. Toxicology Reports, 2, 289-296. https://doi.org/10.1016/j.toxrep.2015.01.008

[6] Zhao, Y., Xie, L. and Yan, Y. (2015) Microcystin-LR Impairs Zebrafish Reproduction by Affecting Oogenesis and Endocrine System. Chemosphere, 120, 115-122. https://doi.org/10.1016/j.chemosphere.2014.06.028

[7] Hou, J., Su, Y., Lin, W., Guo, H., Xie, P., Chen, J., Gu, Z. and Li, L. (2017) Microcystin-LR Retards Gonadal Maturation through Disrupting the Growth Hormone/Insulin-Like Growth Factors System in Zebrafish. Ecotoxicology and Environmental Safety, 139, 27-35. https://doi.org/10.1016/j.ecoenv.2017.01.025

[8] Yoshizawa, S., Matsushima, R., Watanabe, M.F., Harada, K.I., Ichihara, A., Carmichael, W.W. and Fujiki, H. (1990) Inhibition of Protein Phosphatases by Microcystis and Nodularin Associated with Hepatotoxicity. Journal of Cancer Research and Clinical Oncology, 116, 609-614. https://doi.org/10.1007/BF01637082

[9] Wiedner, C., Visser, P.M., Fastner, J., Metcalf, J.S., Codd, G.A. and Mur, L.R. (2003) Effects of Light on the Microcystin Content of Microcystis Strain PCC 7806. Applied and Environmental Microbiology, 69, 1475-1481. https://doi.org/10.1128/AEM.69.3.1475-1481.2003

[10] Davis, T.W., Berry, D.L., Boyer, G.L. and Gobler, C.J. (2009) The Effects of Temperature and Nutrients on the Growth and Dynamics of Toxic and Non-Toxic Strains of Microcystis during Cyanobacteria Blooms. Harmful Algae, 8, 715-725. https://doi.org/10.1016/j.hal.2009.02.004

[11] Wheeler, T. (2014) Lake Erie Not Alone in Suffering from Harmful Algae. http://www.baltimoresun.com/features/green/blog/bal-lake-eries-water-woes-strike -home-20140805-story.html

[12] D’Anglada, L. (2017) Health and Ecological Effects. U.S. Environmental Protection 
Agency. https://www.epa.gov/nutrient-policy-data/health-and-ecological-effects

[13] Paerl, H.W., Fulton, R.S., Moisander, P.H. and Dyble, J. (2001) Harmful Freshwater Algal Blooms, with an Emphasis on Cyanobacteria. The Scientific World Journal, 1, 76-113. https://doi.org/10.1100/tsw.2001.16

[14] Metcalf, J.S., Hyenstrand, P., Beattie, K.A. and Codd, G.A. (2000) Effects of Physicochemical Variables and Cyanobacterial Extracts on the Immunoassay of Microcystin-LR by Two ELISA Kits. Journal of Applied Microbiology, 89, 532-538. https://doi.org/10.1046/j.1365-2672.2000.01141.x

[15] Dolman, A.M., Rücker, J., Pick, F.R., Fastner, J., Rohrlack, T., Mischke, U. and Wiedner, C. (2012) Cyanobacteria and Cyanotoxins: The Influence of Nitrogen versus Phosphorus. PLoS ONE, 7, e38757.

https://doi.org/10.1371/journal.pone.0038757

[16] Engström-Öst, J., Repka, S. and Mikkonen, M. (2011) Interactions between Plankton and Cyanobacterium Anabaena with Focus on Salinity, Growth and Toxin Production. Harmful Algae, 10, 530-535. https://doi.org/10.1016/j.hal.2011.04.002

[17] Tonk, L., Bosch, K., Visser, P.M. and Huisman, J. (2007) Salt Tolerance of the Harmful Cyanobacterium Microcystis aeruginosa. Aquatic Microbial Ecology, 46, 117-123. https://doi.org/10.3354/ame046117

[18] Ek, P., Ek, B. and Zetterqvist, Ö. (2015) Phosphohistidine Phosphatase 1 (PHPT1) Also Dephosphorylates Phospholysine of Chemically Phosphorylated Histone H1 and Polylysine. Upsala Journal of Medical Sciences, 120, 20-27. https://doi.org/10.3109/03009734.2014.996720 